\title{
Assistance in identifying potential occupational safety and health hazards for woven bamboo craftsmen in Tasikmalaya
}

\author{
Isyeu Sriagustini ${ }^{1^{*}}$, Teni Supriyani ${ }^{2}$ \\ ${ }^{1,2}$ STIKes Respati, Tasikmalaya Jawa Barat \\ *E-mail: isyeutnt@gmail.com
}

\author{
Submitted article Aprill, 272021 \\ Review Article Augustus, 132021 \\ Acceptad article :Augistus 16, 2021
}

\begin{abstract}
The informal sector business supports the economy in Indonesia. However, It has various potential hazards. Occupational safety and health (OSH) must be implemented in all workplaces, both formal and informal. OSH efforts focus more on disease prevention and health promotion to change workers' behavior meeting occupational health standards. One of them is increasing workers' knowledge. This community service aims to disseminate the study results of the potential hazards of the work environment in each process of making bamboo weaving crafts. The method used community empowering There were 20 participants consisting of bamboo SMEs owners and the craftsmen who joined the bamboo SMEs association. The results showed that most participants never knew that there were potential hazards in every stage of making woven bamboo crafts before the accompaniment. However, they became more understanding of the potential hazards in their workplace after accompaniment. In conclusion, craftsman's understanding levels of the potential hazards in the work environment increased after accompaniment. potential hazards in the process of making bamboo crafts. SMEs owners and artisans should consider potential risks in the workplace to form safe behavior at work.
\end{abstract}

Keywords: Potential hazard; Bamboo crafts; Craftsman; Occupational safety and health

\section{INTRODUCTION}

Informal sector business has the characteristics of being small-scale, owned by individuals or families, using simple technology, being labor-intensive, having low education and labor skills, and relatively low wage levels (Bappenas, 2009). It usually is a form of Small and Medium Enterprises (SMEs). It supports the economy in Indonesia with significant labor absorption. In February 2020, the workforce was 137.91 million people, while the working population was 131.03 million, with 74.04 million people $(56.5 \%)$ working in informal activities (BPS, 2020). One of the most numerous SMEs in Tasikmalaya Regency is bamboo handicraft SMEs. Leuwisari is one of the sub-districts in Tasikmalaya Regency with the highest number of bamboo handicraft SMEs. In addition, There are 430 craftsmen in Leuwisari District spread over nine villages. 147 of them are at Jayamukti Village (BPS Kabupaten Tasikmalaya, 2020).

As is the case with formal sector business, informal sector business also has various potential occupational hazards that risk health and safety. Bamboo has a potential threat that is riskier to health and works safety than other crafting materials. According to research Sriagustini and Supriyani (2021), there were about 23 potential hazards in making woven bamboo. Approximately $63.3 \%$ of them were a potential hazard with a moderate level of risk, so it needs immediate hazard control.

Unlike the formal sector businesses that have received sufficient attention from the government in occupational health, the informal sector business has not entirely accepted the same attention. Informal sector business usually does not get good occupational health services. In contrast, occupational health and safety (OHS) aim to protect workers from potential hazards of the work environment to remain healthy and productive. Occupational health efforts must be carried out in all formal and informal workplaces (RI, 2009). It is because 
all workplaces have potential health hazards originating from the work environment. The work environment is an additional burden, in addition to the workload itself. Good workload management and work environment create healthy laborers and increase productivity (Suma'mur 2009).

Occupational safety and health (OSH) are knowledge and application efforts to prevent accidents and occupational diseases. Health efforts must be carried out comprehensively, including disease prevention, health improvement, disease treatment, and health restoration. Health efforts should focus on prevention and health improvement aiming to change the health behavior in workers, to reduce or eliminate the risk of accidents and occupational diseases. Efforts in health improvement based on occupational health standards increase health knowledge, cultivate clean and healthy living behavior, and occupational safety and health in the workplace (RI, 2019). With a better understanding of the potential hazards, workers will be more careful and not underestimate the health and safety risks in making woven bamboo crafts. Hartono's (2018) research showed that knowledge affected perception in occupational Health and Safety (OHS) implementation with an influence level of 5.6\%. It is in line with a study conducted by Windhiarni (2017). The study stated that the knowledge variable contributes $14.5 \%$ to the awareness of OSH behavior.

Based on the background, artisans need to know the potential hazards in the work environment - especially in making woven bamboo - to work healthily and safely. Therefore, the purpose of this community service is to socialize the study results regarding the potential hazards of the work environment in each process of making woven bamboo crafts in artisans and craft owners to increase their understanding.

\section{GENERAL DESCRIPTION OF THE COMMUNITY, PROBLEMS, AND TARGET SOLUTIONS}

\section{General Description}

Serumpun Bamboo SMEs is located on RT 10 RW 05 Kampung Nangorak, Jaya Mukti Village, Leuwisari District, Tasikmalaya Regency. It is a home industry engaged in the manufacture of various woven bamboo products. There are permanent craftsmen with an age range of 43-70 years, elementary and junior high school education, and approximately 25 years of working years, while non-permanent artisans are from neighboring around the industrial area. Local communities usually weave or make handicraft materials to fill their spare time, later sold to SMEs. The method of making woven bamboo crafts is generally divided into two stages: 1) Making woven materials as the primary material for crafts. The process starts from cutting bamboo, making bamboo strands, to making plaits. 2) Creating bamboo weaving products. The manufacture of woven bamboo products differs in the activity stage from one product to another, especially when preparing additional materials and assembling the product.

\section{Problem}

This community service activity implemented research results entitled "Identifying potential work environment hazards on woven bamboo craftsmen at Jayamukti Village, Leuwisari District, Tasikmalaya Regency." The study results showed that all stages of making woven bamboo crafts had potential hazards from the work environment, causing health problems and work accidents. In the step of making woven materials, there were 23 potential hazards, with details of 2 potential physical hazards, 5 potential chemical hazards, 6 potential ergonomic hazards, and 10 potential mechanical hazards. Meanwhile, there were 16 potential hazards in preparing additional materials, with details of 2 potential chemical hazards, 4 potential ergonomic hazards, and 10 potential mechanical hazards. In assembling bamboo weaving products, there were 23 potential hazards with details of 6 potential ergonomic hazards and 17 potential mechanical hazards. Finally, there were 9 potential hazards in the finishing process with detail of 2 potential physical hazards, 3 potential chemical hazards, and 4 potential ergonomic hazards.

\section{Target Solutions}


The craftsmen did not comprehend the research results above. Therefore, the authors carried out socialization of potential hazards in the workplace and OSH to increase knowledge and hazard controls.

\section{METHOD}

This community service activity was carried out with community empowering the potential hazards in the work environments, especially in each stage of making woven bamboo crafts. It was carried out directly with health protocols. It took place at Serumpun Bamboo SMEs, Jayamukti Village, Leuwisari District, on Wednesday, July 22, 2020. Twenty participants consisted of owners of bamboo SMEs and the craftsmen who joined the bamboo SMEs association. The implementation stages were as follows:

1. Preparation:

1) We studied the potential hazards in each work process by observing each stage and interviewing artisans in charge of making woven bamboo crafts.

2) Data analysis and study results.

3) Coordination with bamboo SMEs association. Then preparation of activity plans, budgets, and events for socialization.

\section{Implementation}

The accompaniment was carried out by two sources, namely from the Leuwisari Public Health Center and the community service team of STIKes Respati. The material consisted of occupational Health and Safety (OHS) and potential hazards in the work environment, especially in each process of making woven bamboo crafts

3. Evaluation

The evaluation used a questionnaire consisting of potential hazards in the process of making woven bamboo crafts before and after the socialization

\section{RESULTS AND DISCUSSION}

In the implementation, sources delivered research results to participants. The socialization process was going well. Even in the discussion session, participants were surprised when realizing there were many potential hazards in each stage of making woven bamboo crafts. After the socialization, we evaluated the knowledge in participants.

Table 1: Participants' Knowledge of the Potential Hazards in Each Stage of Making Woven Bamboo Crafts

\begin{tabular}{|c|c|c|c|}
\hline Questions & Yes & $\begin{array}{l}\text { Answers } \\
\text { Doubtful }\end{array}$ & No \\
\hline $\begin{array}{l}\text { Have you previously been aware of the potential hazards in each stage of } \\
\text { making woven bamboo crafts? }\end{array}$ & 1 & 3 & 16 \\
\hline $\begin{array}{l}\text { After participating in this activity, do you know that there are potential hazards } \\
\text { in every stage of making woven bamboo crafts? }\end{array}$ & 18 & 2 & 0 \\
\hline
\end{tabular}
Source: Primary Data

Most participants never knew that there were potential hazards in every stage of making woven bamboo crafts (table 1). They did not understand that the materials, tools, and work processes had potential hazards. In addition, when the potential hazard becomes a threat, they did not respond to it or as if it is normal. They believed that consequences caused by the hazard are not severe or did not cause death. However, occupational hazards must be controlled because the purpose of OHS is to protect workers from all potential risks in the workplace so that workers can live and increase work productivity (RI, 1970). 
Table 2: The Craftsman's Understanding Levels of the Potential Hazards in Each Stage of Making Woven Bamboo Crafts before and after socialization.

Understanding levels

$\begin{array}{ll}\begin{array}{l}\text { Before } \\ (n=20)\end{array} & \text { After } \\ (n=20)\end{array}$

frequency Percentag frequency Percentag

$\mathrm{e}(\%) \quad \mathrm{e}(\%)$

Classifying the potential hazards in the work environment

based on the stages of making woven bamboo crafts

\begin{tabular}{r|cccc} 
Understand & 5 & 25 & 18 & 90 \\
Do not understand & 15 & 75 & 2 & 10
\end{tabular}

Classifying the potential hazards in the work environment based on the types of the potential hazard

$\begin{array}{rcccc}\text { Understand } & 1 & 5 & 11 & 55 \\ \text { Do not understand } & 19 & 95 & 9 & 45\end{array}$

Source: Primary Data

Table 2 describes that there are increased understanding levels in participants after socialization. Knowledge is the result of knowing and occurs after sensing a particular object. Meanwhile, understanding is a level of knowledge that can explain things that are known correctly or correctly interpret a material presented (Notoatmodjo, 2017). Knowledge plays an essential role in forming a person's actions or behavior. Therefore, knowledge about occupational safety and health (OSH) establishes safe and healthy behavior in workers. The most basic knowledge in OSH is comprehending potential hazards in the workplace.

The accident causes consist of two aspects, unsafe conditions and behavior. Unsafe conditions are usually related to places, work processes, or tools that have potential hazards. Meanwhile, unsafe behavior refers to incorrect actions or do not comply with safety procedures. It usually occurs due to a lack of understanding of tools, materials, work processes, and potential hazards in the workplace. Bad attitude and work behavior can later cause work accidents (Suma'mur 2009).

This study result is in line with other previous researches. A study by Murtinugraha (2021) reported that the education given to builders regarding $\mathrm{OSH}$ in construction increased their understanding. In addition, education provided to fishers about OSH also increased their knowledge and attitude in preventing and overcoming occupational health and safety problems so that their health status could improve (Desita, 2020). Furthermore, Wahyu (2019) reported that counseling and mentoring elevated the average knowledge score in blacksmith artisans regarding OSH, especially noise hazards in the workplace. Likewise, their attitude in the use of PPE appropriately improved. In brief, promotion efforts in the workplace can be made by providing information, education, assistance, and other knowledge-building efforts to improve health status according to standards (RI, 2019).
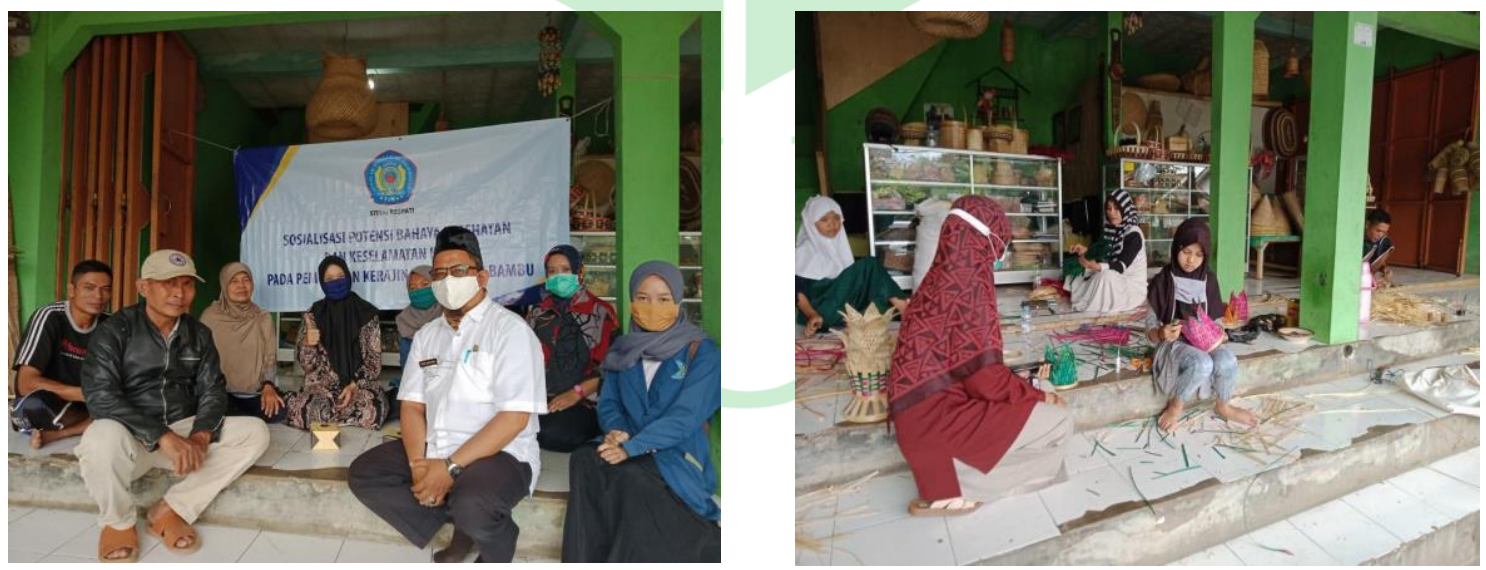

Figure 1: Assistance of Potential Hazards in the Process of Making Bamboo Crafts

Assistance In The Management Of Wood Waste For Wood Craftsmen In Tasikmalaya Isyeu Sriagustini , Teni Supriyani 


\section{CONCLUSION AND SUGGESTION}

Craftmans' understanding levels of the potential hazards in the work environment increased after socializing potential hazards in the process of making bamboo crafts. SMEs owners and artisans should consider potential risks in the workplace to form safe behavior at work.

\section{ACKNOWLEDGEMENTS}

We gratefully acknowledge The Institute for Research and Community Service (LPPM) of STIKes Respati, Leuwisari Public Health Centre (PHC), owners of SMEs, bamboo craftsmen association, and woven bamboo artisans at Jayamukti Village, Leuwisari District, Tasikmalaya Regency.

\section{REFERENCES}

Bappenas (2009) Kajian Evaluasi Pembangunan Sektoral : Peran Sektor Informal Sebagai Katup Pengaman Masalah Ketenagakerjaan. Jakarta: Bappenas.

BPS (2020) Februari 2020: Tingkat Pengangguran Terbuka (TPT) Sebesar 4,99 Persen. Badan Pusat Statistik. www.bps.go.id.

BPS Kabupataen Tasikmalaya (2016) Sensus Ekonomi 2006 Hasil Listing: Potensi Ekonomi Kabupaten Tasikmalaya. Tasikmalaya: BPS Kabupaten Tasikmalaya. , (2020) Kecamatan Leuwisari dalam Angka 2020. Tasikmalaya: BPS Tasikmalaya.

Desita, R. (2020) 'Edukasi Kesehatan Kerja pada Kelompok Nelayan’, Jurnal Abdimas Saintika, 2(2), pp. 91-96.

Hartono, A. (2018) 'Pengaruh Pengetahuan, Sikap, Dan Kondisi Lingkungan Kerja Terhadap Presepsi Penerapan Keselamatan Dan Kesehatan Kerja', Jurnal Dinamika Vokasional Teknik Mesin, 3(2), pp. 76-81.

Murtinugraha, R. E. (2021) 'Peningkatan pemahaman K3 Pekerja Kontruksi Bagi Tukang Bangunan di Kecamatan Muara Gembong kabupaten Bekasi’, Jurnal Abditek, 1(1), pp. 60-70.

Notoatmodjo, S. (2017) Ilmu Perilaku Kesehatan. Jakarta: Rineka Cipta.

RI (2009) Undang-Udang Nomor 36 Tahun 2009 Tentang Kesehatan. Indonesia: Republik Indonesia.

, Peraturan Pemerintah Republik Indonesia Nomor 88 Tahun 2019 Tentang Kesehatan Kerja. Jakarta: Kementrian Sekertariat Negara RI.

Sriagustini, I. and Supriyani, T. (2021) 'The Risk Assessment on Bamboo Weaving Craftsmen in Rajapolah District Tasikmalaya Regency', The Indonesian Journal Of Occupational Safety and Health, 10(1), pp. 64-78.

Suma'mur, P. K. (2009) Higiene perusahaan dan kesehatan kerja (HIPERKES). Jakarta: Sagung Seto.

Wahyu, A. (2019) 'Metode Edukasi \& Pendampingan Terhadap Peningkatan Kesadaran Terkait Penggunaan APT pengrajin Pandai Besi’, JKMM, 2(2), pp. 302-313.

Windhiarni, E. (2017) 'Pengaruh Pengetahuan K3 dan Sikap Terhadap Kesadaran berprilaku K3 di Bengkel Permesinan SMK XYZ Sidoardjo', in SNST Ke18. Semarang: Fakultas Teknik Universitas Wahid HAsyim Semarang, pp. 54-59. 